\title{
Urgences
}

\section{La folie...}

\section{Manuel Marienval}

Numéro 13, mars 1986

\section{Éclats d'atelier}

URI : https://id.erudit.org/iderudit/025216ar

DOI : https://doi.org/10.7202/025216ar

Aller au sommaire du numéro

\section{Éditeur(s)}

Urgences

\section{ISSN}

0226-9554 (imprimé)

1927-3924 (numérique)

Découvrir la revue

\section{Citer ce document}

Marienval, M. (1986). La folie... Urgences, (13), 38-38.

https://doi.org/10.7202/025216ar d'utilisation que vous pouvez consulter en ligne.

https://apropos.erudit.org/fr/usagers/politique-dutilisation/ 


\section{Manuel Marienval}

La folie, simple lubie m'exaltant comme un fruité, toqué, un dingo hébété et débile, tel un poètes s'enivrant de punch fruité, orange et cassis. Et puis la vodka m'absorbe, l'odeur m'enivre d'excès, de broue de bière, d'une crise de rires d'une foule d'anges saouls. La danse continue et chavire, légère, tandis que Jules, bourré et bourru comme un marin, déballe le drame d'un héros crétin et évasif. L'idiot s'échappe de l'asile pour esquisser la fuite de... Jules ne termine pas le récit, une folle s'entiche de l'homme discourant et n'rrive plus à șe contenir, à se dominer, moins encore à ressaisir le désir, l'amour, la folie de la chair vierge et chaude invitant l'amant matois au dîner de l'enfer génial. La faute, le délit, l'excès, le crime et le péché subtil enchantaient Jules. Se découvrir cinglé, se conserver timbré et devenir dingue comme un clown. Seulement, l'usage hésite encore. La prose et l'objet s'accouplent au coeur du texte libéré. Le verbe éclipse le sujet séduit, ébloui par la folie légère du génie braque dans I'antre du djinn. Jules, résolu de la plume, compose l'alibi du refus. Sévère et obscur, l'éfrit médite la forme opaque, parfois trop longue parfois trop courte, de. l'image simulant le songe, présageant la folie. 